\title{
Waterfront city development di kawasan sempadan sungai: Studi kasus Sungai Wiso dan Kanal, Jepara
}

\section{Yoga Putra Prameswari}

Institute for Development and Economic Analysis (IDEA) Yogyakarta, Indonesia

\section{INTISARI}

Tulisan ini bermaksud menganalisis implementasi kebijakan pengelolaan kawasan sempadan sungai di Kabupaten Jepara, serta membingkainya dalam konsepsi waterfront city development. Penelitian ini menggunakan implementasi kebijakan publik dari Merilee Grindle. Menurut Grindle, keberhasilan suatu implementasi kebijakan publik sangat ditentukan oleh derajat dari level implementasi tersebut, yang terdiri dari content of policy dan context of implementation. Content of policy merujuk pada substansi yang terkandung di dalam kebijakan publik, sedangkan context of implementation merupakan representasi dari lingkungan dimana kebijakan publik itu akan berlangsung. Implementasi kebijakan publik ini berhasil dikarenakan policy statement dapat tersampaikan menjadi policy outcome. Metode yang digunakan di dalam penelitian ini adalah studi kasus dengan pendekatan kualitatif. Studi kasus merupakan metode penelitian terhadap satu kasus yang dilakukan secara intensif dan mendalam.

\section{KATA KUNCI}

Analisis terhadap

Kebijakan; Evaluasi

Kebijakan; Kawasan

Sempadan Sungai;

Waterfront City

Development

\section{Pendahuluan}

$\mathrm{P}$

ada awal abad ke-16, Jepara merupakan salah satu bandar perdagangan terpenting di pesisir utara Jawa, selain Lasem, Tuban, dan Sunda Kelapa (Toer, 2002). ${ }^{1}$ Selain itu, Jepara dikenal pula sebagai industri galangan kapal oleh para pelaut (Lombard, 2000: 54). Kemasyhuran Jepara sebagai bandar dikarenakan letak geografisnya yang strategis, berada di pesisir (paling) utara Jawa, dilalui jalur perdagangan Malaka - Maluku, dan ditunjang keberadaan sungai. Keberadaan sungai memperlancar jalur perdagangan dan transportasi, apalagi jalur transportasi kala itu masih didominasi jalur perairan dibandingkan darat. Perahu silih berganti mengangkut komoditas pertanian/perkebunan dari daerah pedalaman ke pelabuhan, maupun sebaliknya; melalui sungai-sungai tersebut.

\section{Korespodensi:}

Perkumpulan Idea Yogyakarta, Jalan Kaliurang KM. Gang Tejomoyo CT III/3, Depok, Karang Wuni, Caturtunggal, Sleman, Kabupaten Sleman, Daerah Istimewa Yogyakarta 55284

Email: bubudafreak@gmail.com 
Seorang pemerhati sejarah Jepara, Tabrani, beberapa waktu yang lalu mengatakan bahwa penemuan benda arkeologi yang berupa kapal kayu di Pasar Ratu, menguatkan kembali tentang sejarah keberadaan "Foort Japara" dan Loji Gunung yang terletaknya di sebelah barat sungai Wiso. Masih menurut Tabrani, fungsi pelabuhan Jepara saat itu sangat mirip dengan Singapura, dimana letaknya sangat strategis untuk kepentingan perdagangan. Pelabuhan Jepara tidak ubahnya seperti pelabuhan jasa, dan tak jarang kapal niaga dari Tiongkok, India, hingga Eropa singgah di pelabuhan ini ("Menyimpan Sejarah Kehebatan Ratu Kalinyamat," 2008). Dengan adanya penemuan benda arkeologi di atas, sekiranya kita dapat merekonstruksikan kondisi Jepara tempo dulu sebagai daerah yang berada di pesisir utara Jawa, serta bersebelahan langsung dengan laut Jawa, kemudian menjadi lalu lintas perdagangan yang ramai hingga menjadi sebuah bandar. Selain itu, kondisi ini membuktikan sejarah Jepara sebagai bandar dan menjadi salah satu tempat singgahnya kapal-kapal niaga di jalur perdagangan internasional pada abad ke-16.

Berbeda kondisi dengan beberapa abad lalu, beberapa sungai di Jepara telah mengalami pergeseran fungsi. Salah dua contohnya adalah Sungai Wiso dan Kanal. Saat ini, baik Wiso dan Kanal, hanya berfungsi sebagai Daerah Aliran Sungai (DAS) dan pembuangan limbah rumah tangga masyarakat. Lebarnya pun telah menyempit disebabkan pendangkalan dan pemukiman liar masyarakat sepanjang kawasan sempadannya. Dengan kondisi seperti ini, Wiso dan Kanal selalu disergap tingginya debit air hujan di Jepara.

Beranjak dari narasi relasi sungai dan perkembangan kota, mulai dari historiografi sampai paradigma pembangunan kawasan perkotaan, tentunya menarik mengelaborasi efektifitas kebijakan pengelolaan kawasan sempadan sungai di Jepara, khususnya level implementasi kebijakan. Dalam hemat penulis, ada tiga kausa mengapa studi ini menarik. Pertama, belum banyak kajian tentang sempadan sungai yang dikerangkai dari sisi analisis terhadap kebijakan di Indonesia. Kedua, studi pembangunan kawasan perkotaan merupakan studi yang dinamis dan kontemporer, terutama dalam sosial politik. Ketiga, belum banyaknya kabupaten/kota yang mempunyai implementasi kebijakan publik berorientasi tata kelola sungai dan kawasan sempadannya.

Analisis kebijakan publik merupakan disiplin ilmu sosial terapan yang menggunakan berbagai metode penelitian beserta argumentasinya, untuk menghasilkan dan memindahkan informasi yang relevan sehingga di level politik dapat dimanfaatkan untuk memecahkan masalah kebijakan (Dunn dan Darwin dalam Subarsono, 2006: 2). Analisis kebijakan publik merupakan aktifitas intelektual yang dilakukan dalam sebuah proses politik, tetapi tidak menggantikan proses politik itu sendiri, alih-alih mensubstitusikan dengan pendekatan teknokratis. Menurut Dunn, analisis kebijakan publik harus diletakkan sebagai konteks, bukan konten (Subarsono, 2006)

Dalam kajian analisis kebijakan, ada dua perspektif analisis, yakni perspektif yang dibangun diatas premis obyektifitas analisis dan perspektif yang dibangun diatas prinsip inter-subyektifitas analisis (Santoso, 2010: 8). Perspektif pertama berkontribusi terhadap perkembangan tradisi analisis terhadap kebijakan (analysis of policy), sedangkan perspektif kedua berkontribusi terhadap tradisi analisis untuk kebijakan (analysis for policy). Bahasa sederhananya, analisis untuk kebijakan merupakan analisis yang digunakan dalam pembuatan kebijakan publik, sedangkan analisis terhadap kebijakan merupakan analisis yang bersifat mengkritisi kebijakan publik. Ditinjau dari 
waktunya, analisis untuk kebijakan dapat dilakukan saat kebijakan tersebut belum ataupun sudah dilaksanakan, sedangkan analisis terhadap kebijakan, analisis kebijakannya dilakukan saat kebijakan tersebut sudah terlaksana. Tipologi analisis terhadap kebijakan akan menghasilkan berbagai masukan/pertimbangan yang berguna untuk menyempurnakan kebijakan publik yang telah ada, atau sebagai bahan masukan untuk kebijakan publik selanjutnya, bahkan sebagai teori kebijakan publik yang baru. ${ }^{2}$ Dalam tulisan ini, analisis terhadap kebijakan (analysis of policy) yang dipakai sebagai pisau analisis. Untuk mengerjakannya, akan mengkerangkai dua basis teori, yakni Implementasi Kebijakan yang dirumuskan Grindle dan konsep Waterfront City Development.

Menurut Grindle (1980), implementasi kebijakan harus mempertimbangan berbagai aspek/ dimensi. Keberhasilan implementasi kebijakan publik sangat ditentukan oleh implementasi, yang terdiri dari content of policy dan context of implementation. Content of policy adalah substansi yang terkandung didalam kebijakan publik, sedangkan context of implementation merupakan representasi dari lingkungan dimana kebijakan publik tersebut akan berlangsung. Content of policy dapat mempengaruhi proses implementasi kebijakan dikarenakan policy content yang dihasilkan melalui proses penyusunan kebijakan menentukan apa yang harus tersampaikan melalui sebuah kebijakan, perubahan apa yang bakal muncul sebagai akibat dari kebijakan yang diimplementasikan, dimana kebijakan tersebut diimplementasikan, dan siapa yang mengimplementasikan kebijakan tersebut (Grindle, 1980: 8-10). Dalam skope content of policy, Grindle (1980) menyatakan bahwa ada 6 elemen yang harus diperhatikan, yaitu: interest affected, type of benefits, extend of change envision, site of decision making, program implementer, resources comitted. Sedangkan dalam skope context of implementation, terdiri dari 3 elemen, yaitu kekuatan, kepentingan, strategi aktor yang terlibat (power, interest, and strategy of actor involved); karakteristik rejim/institusi (institution and regime characteristic); kepatuhan dan responsifitas (compliance and responsiveness).

Pasca implementasi, sebuah kebijakan publik membutuhkan sebuah mekanisme pengawasan yang bertujuan mengukur efektifitasnya. Mekanisme pengawasan ini dikenal publik dengan evaluasi kebijakan. Evaluasi kebijakan dapat disamakan dengan penaksiran/appraisal, pemberian angka/ rating, dan penilaian/ assesment (Dunn, 1999: 608-610). Ada 6 kriteria evaluasi kebijakan publik, meliputi : efektifitas, efisiensi, kecukupan, perataan, responsivitas, dan ketepatan (Dunn, 1999). Ditinjau dari waktunya, evaluasi kebijakan publik terbagi kedalam 3 tipologi, yakni sebelum dilaksanakan, sedang dilaksanakan, dan setelah dilaksanakan. Evaluasi kebijakan publik pada waktu pelaksanaan biasanya disebut evaluasi proses, sedangkan evaluasi setelah pelaksanaan disebut sebagai evaluasi konsekuensi (output) kebijakan dan/atau evaluasi dampak (outcome) kebijakan, atau sebagai evaluasi sumatif.

Konsepsi Waterfront City Development berawal dari kebangkrutan kota bandar di Amerika Serikat Tahun 1970-an akibat resesi ekonomi. Salah satu kota bandar yang mengalami kebangkrutan adalah Baltimore. Beruntungnya, negeri Paman Sam mempunyai seorang urban visioner dalam diri James Rouse. Melalui pendekatan pembangunan dalam pengelolaan kota bandar, Rouse mampu menyelamatkan Baltimore dari keterpurukan ekonomi. Pendekatan Rouse dalam membangkitkan Baltimore menjadi salah satu fase penting dalam pembangunan kota, sekaligus menjadi salah satu cetak biru perencanaan pembangunan di beberapa kota bandar, baik di Amerika Serikat maupun 
dunia. Peristiwa ini merupakan awal mula kelahiran penataan ulang kawasan bandar lama yang disebarluaskan media massa sebagai pembangunan waterfront city (Yuwono, 2009: 2).

Waterfront city development dapat dioperasionalkan jika memenuhi prasyarat dan pertimbangan tertentu. Prabudiantoro (1997) menjelaskan 5 kriteria umum perancangan waterfront city development di kawasan perkotaan, antara lain : (1) Berlokasi di tepi suatu wilayah perairan yang besar (sungai, danau, laut, dan sebagainya), (2) Biasanya merupakan area pelabuhan, perdagangan, permukiman, dan pariwisata, (3) Mempunyai fungsi utama sebagai tempat rekreasi permukiman, industri, dan pelabuhan, (4) Pemandangan berorientasi ke arah perairan, dan (5) Pembangunannya dilakukan ke arah vertikal horisontal.

Sedangkan Breen (1996) membagi konsep waterfront city development ke dalam 4 tipologi utama berdasarkan sifat dan jenis aktifitasnya, yakni: mixed-used waterfront, recreational waterfront, residental waterfront, working waterfront. Dalam mixed-used waterfront, kawasan tepian air difungsikan untuk menampung aktifitas-aktifitas yang berbeda karakter ke dalam sebuah kawasan kota yang terintegrasi, semisal permukiman, perkantoran, perniagaan, tempat kebudayaan, dan sebagainya; sedangkan dalam recreational waterfront, kawasan tepian air difungsikan untuk aktifitas rekreasi masyarakat. Adapun residental waterfront, kawasan tepian air difungsikan sebagai permukiman, sedangkan dalam working waterfront, kawasan tepian air difungsikan untuk aktifitas pekerjaan masyarakat setempat.

Analisis kebijakan publik ini merupakan hasil dari penelitian yang bersifat kualitatif, dengan metode studi kasus. Secara definitif, studi kasus merupakan pendekatan penelitian terhadap satu kasus yang dilakukan secara intensif dan mendalam (Narbuko, 2003: 164). Penggunaan metodologi studi kasus di dalam penelitian didasarkan adanya teori yang telah dipaparkan pada bagian landasan teori, tidak secara tegas mengikat proses penelitian, konsep-konsep yang ada pada teori tersebut bersifat fleksibel hanya bersifat mengarahkan (Sarantakos, 1999: 15). Selain itu, metode studi kasus digunakan pula untuk menjawab pertanyaan mengapa (why) dan bagaimana (how) dalam sebuah perangkat peristiwa yang diteliti (Yin, 2006: 1).

\section{Pengelolaan Kawasan Sempadan Sungai di Jepara}

Di Jepara, terdapat dua sungai besar yang membelah kawasan perkotaan, yakni sungai Wiso dan Kanal. Keduanya berhulu sama, namun berbeda muara. Daerah yang dilalui kedua sungai ini cenderung berbeda. Bentang sungai Wiso dimulai dari Bapangan, Saripan, Pengkol, Panggang, Jobokuto, Ujungbatu, dan berakhir di Laut Jawa, sedangkan sungai Kanal dari Tahunan, Senenan, Kecapi, Bapangan, Saripan, Potroyudan, Krapyak, Demaan, Bulu, dan berakhir di Laut Jawa. Menurut seorang sejarawan Jepara, Tabrani, dulu sungai Wiso merupakan sungai besar dan lebar sehingga menjadi tempat persinggahan kapal niaga dari Tiongkok. Lanjut Tabrani, lebar lebar sungai Wiso saat itu cukup untuk tiga kapal dagang ("Menyimpan Sejarah Kehebatan Ratu Kalinyamat," 2008).

Pada abad ke-18, kawasan perairan bandar Jepara tidak lagi aman dilayari kapal-kapal niaga. Beberapa teks sejarah menyebutkan, pelabuhan Jepara mulai mengalami pendangkalan di muara sungai yang disebabkan sedimentasi lumpur dari hulu sungai ("Menyimpan Sejarah Kehebatan Ratu Kalinyamat," 2008). Selain itu, berkembangnya binatang karang yang masif banyak merusak kapal- 
kapal niaga yang singgah disana. Konsekuensi logis dari kondisi ini adalah Belanda menutup kantor dagangnya dan memindahkannya ke Semarang sehingga memperburuk kondisi perekonomian dan perdagangan bandar Jepara. Aktifitas transportasi, perekonomian, dan perdagangan masyarakat yang bergantung pada dimensi air mulai sepi, bahkan sampai beberapa abad kemudian.

Setelah republik Indonesia ini berdiri, Pemkab Jepara cenderung memprioritaskan pembangunan ekonomi, infrastruktur, dan kerajinan ukir dibandingkan pembangunan berbasiskan ekologi, semisal pengelolaan sungai beserta kawasan sempadannya, baik di Sungai Wiso dan Kanal. Tidak jarang kawasan perkotaan Jepara mengalami banjir akibat Sungai Wiso maupun Kanal tak mampu menampung debit air hujan. ${ }^{3}$ Kutipan tajuk rencana dibawah ini setidaknya menggambarkan peristiwa banjir di Jepara tahun 2005 ("Banjir di Jepara itu Sebuah Peringatan," 2005):

Pada 7 Januari lalu, air sungai Wiso yang melintang di jalur utama kota, tepatnya di Jalan Pemuda di sebelah timur gedung DPRD, meluap. Luapan air juga terjadi di Sungai Kanal, sudetan Sungai Wiso di Potroyudan, melampaui fondasi setinggi setengah meter. Dalam waktu kurang dari satu jam, seluruh jalan kota lumpuh total.

Padahal dalam dua dasawarsa terakhir, peristiwa banjir jarang menghampiri kawasan perkotaan Jepara. Banjir tahun 2005 lalu merupakan peristiwa banjir kedua di era millenium, setelah tahun 2002. Penyebabnya adalah terkikisnya lahan kritis di lereng Muria yang berdekatan dengan Batealit, serta disfungsi kawasan resapan di kawasan hulu Sungai Wiso dan Kanal ("Banjir di Jepara itu Sebuah Peringatan," 2005). ${ }^{4}$ Disfungsi kawasan resapan di kawasan hulu diperparah dengan pendangkalan/penyempitan DAS di sepanjang Sungai Wiso dan Kanal. Kenyataannya, di sepanjang kedua DAS tersebut berjejal bangunan ilegal permanen maupun semi permanen, dan hanya sebagian kecil bangunan yang legal/ berijin (Anis, wawancara penulis, 27 Oktober 2010). Bangunan yang didirikan di DAS Sungai Kanal sampai jembatan Pamatan, kesemuanya tidak berijin. Paradoksnya, bangunan yang berdiri mulai dari jembatan Pamatan sampai ke muara sungai, sebagian besar sudah memiliki IMB. Selain itu, kedua sungai tersebut nyatanya mengalami degradasi fungsi yang cukup parah, seperti sedimentasi yang masif, banyaknya sampah pada area DAS, air sungai yang keruh/berwarna, serta berbau anyir. Kondisi ini diperparah dengan ketidaktegasan aparatur pemerintah dalam menjalankan peraturan yang bersifat legal formal, maupun yang berbentuk kebijakan publik. Alih-alih melakukan tindakan tegas, regulasinya tak cukup mengikat.

Dalam konteks kebijakan publik ini, Pemkab Jepara mengacu pada Undang Undang Nomor 32 Tahun 2009 tentang Perlindungan dan Pengelolaan Lingkungan Hidup (selanjutnya disebut UU PPLH). Substansi dari undang-undang ini adalah pembangunan yang berkelanjutan atau sustainable development. Pembangunan yang berkelanjutan adalah sebuah upaya sadar dan terencana yang memadukan aspek lingkungan hidup, sosial, dan ekonomi ke dalam keselamatan, kemampuan, kesejahteraan, dan mutu hidup generasi kini dan generasi masa depan. ${ }^{5}$ Pembangunan yang berkelanjutan sangat dibutuhkan, tidak hanya untuk melindungi lingkungan sekitar maupun melindungi (pula) kebutuhan generasi mendatang. Dalam sebuah pembangunan yang berkelanjutan, perencanaan yang baik merupakan sebuah keniscayaan dengan catatan mempertimbangkan aspek ekonomi, sosial, lingkungan hidup, dan politik. Pembangunan yang berkelanjutan harus dilakukan secara holistik, serta pemanfaatannya sebesar - besarnya untuk kepentingan masyarakat. 
UU PPLH ini linier dengan Undang Undang Dasar Republik Indonesia Tahun 1945 khususnya Pasal $28 \mathrm{H}$. Secara tersurat, pasal tersebut menyatakan lingkungan hidup yang baik dan sehat merupakan hak asasi setiap warga negara Indonesia. Sebagai mandatoris negara, pemerintah berkewajiban menyediakan lingkungan hidup yang sehat untuk seluruh warga negara Indonesia, tanpa terkecuali satupun. UU PPLH kemudian diturunkan ke dalam RTRWP Jawa Tengah, Pasal 16 huruf $b$ yang mengatur tentang kawasan perlindungan setempat. ${ }^{6}$ Kawasan perlindungan setempat merupakan kawasan yang diperuntukkan bagi kegiatan pemanfaatan lahan yang dapat menjaga kelestarian jumlah, kualitas, kelancaran air, pengaturan dan pemanfaatan air dari sumbersumbernya. Area yang termasuk dalam kawasan perlindungan setempat, antara lain; kawasan sempadan sungai, sempadan pantai, sempadan jalan, kawasan di sekitar mata air, dan kawasan di sekitar danau/waduk/rawa (Perda RTRWP Propinsi Jawa Tengah, Bab V Pasal 17 Ayat 2). Sedangkan untuk tulisan ini, penulis hanya akan membahas tentang kawasan sempadan sungai saja.

RTRWP Jawa Tengah sendiri secara spesifik telah mengatur tentang pengelolaan kawasan sempadan sungai. Beberapa poin yang ada dalam regulasi tersebut diantaranya:

- Pada kawasan sempadan sungai yang belum dibangun, pendirian bangunan tidak diijinkan (ljin Mendirikan Bangunan/IMB tidak diberikan).

- Pada kawasan sempadan sungai yang belum terbangun, masih diperbolehkan kegiatan pertanian dengan jenis tanaman yang diperbolehkan.

- Kegiatan lain yang tidak memanfaatkan lahan secara luas, semisal pemasangan papan reklame/ pengumuman, pemasangan pondasi dan rentangan kabel listrik, pondasi jembatan, dan sebagainya masih diperbolehkan.

- Kegiatan atau bentuk bangunan yang secara sengaja dan jelas menghambat arah dan intensitas aliran air sama sekali tidak diperbolehkan.

- Kegiatan lain yang justru memperkuat fungsi perlindungan kawasan sempadan sungai tetap diperbolehkan dengan pengendalian agar tidak mengubah fungsi kegiatannya di masa mendatang.

Secara tersirat, RTRWP tidak memberikan toleransi kepada bangunan yang berdiri secara permanen di kawasan sempadan sungai. Sayangnya, pemerintah daerah kabupaten/kota tidak mengimplementasikan RTRWP ini. Padahal dalam penyusunan RTRW kabupaten/kota harus mengacu pada RTRW propinsi.

Kawasan sempadan sungai merupakan kawasan sepanjang kanan dan kiri sungai, termasuk sungai buatan, kanal, dan saluran irigasi primer, yang bermanfaat untuk mempertahankan kelestarian fungsi sungai (Perda Nomor 6 Tahun 1998/RTRW Kabupaten Jepara). Adapun garis sempadan sungai merupakan batas kanan dan kiri sepanjang aliran sungai. Kawasan sempadan sungai di setiap kabupaten/kota perlu dilindungi dengan peraturan daerah (Perda), perencanaan pembangunan, dan kebijakan pemerintah yang berkaitan langsung dengan kawasan ini. Perlindungan kawasan sempadan sungai bertujuan untuk melindungi sungai dari kegiatan manusia yang dapat mengganggu, dan/atau merusak kualitas air sungai, serta melindungi kondisi fisik kawasan tepi sungai, dasar sungai, serta mengamankan aliran sungai. 
Bentuk perlindungan garis sempadan sungai di luar permukiman penduduk idealnya adalah 100 meter di bagian kiri dan kanan untuk sungai besar, serta 50 meter untuk bagian kiri dan kanan anak sungai. Untuk kawasan permukiman penduduk, diperlukan upaya membuat sebuah jalan inspeksi yang lebarnya kurang lebih 10-15 meter. Menurut Perda RTRW Kabupaten Jepara, bentang garis sempadan sungai adalah :

- Garis sempadan sungai bertanggul diluar kawasan perkotaan ditetapkan sekurang-kurangnya 5 meter di sebelah luar sepanjang kaki tanggul.

- Garis sempadan sungai bertanggul didalam kawasan perkotaan ditetapkan sekurang-kurangnya 3 meter di sebelah luar sepanjang kaki tanggul.

- Garis sempadan sungai tidak bertanggul diluar kawasan perkotaan pada sungai besar (mempunyai daerah pengaliran seluas 500 kilometer persegi atau lebih) ditetapkan sekurang kurangnya 100 meter, sedangkan pada sungai kecil (daerah pengaliran kurang dari 500 kilometer persegi) sekurang-kurangnya 50 meter dihitung dari tepi sungai pada waktu ditetapkan.

- Sungai mempunyai kedalaman tidak lebih dari 3 meter, garis sempadannya ditetapkan sekurang - kurangnya 10 meter dihitung dari tepi sungai pada waktu ditetapkan.

- Sungai yang mempunyai kedalaman lebih dari 3 meter sampai 20 meter, garis sempadannya ditetapkan sekurang - kurangnya 15 meter dihitung dari tepi sungai pada waktu ditetapkan.

- Sungai yang mempunyai kedalaman maksimum lebih dari 20 meter, garis sempadan sungai sekurang - kurangnya 30 meter terhitung dari tepi sungai pada waktu ditetapkan.

- Pada daerah sempadan dilarang membuang sampah, limbah padat dan atau cair serta mendirikan bangunan permanen untuk hunian dan tempat usaha.

Sedangkan garis sempadan bangunan di tepi sungai ditetapkan dengan dua kategori, yakni sungai yang bertanggul di kawasan perkotaan diukur dari kaki tanggul, untuk bangunan :

- Perdagangan dan jasa ditetapkan 13 meter

- Industri dan pergudangan ditetapkan 23 meter

- Bangunan umum lainnya ditetapkan 8 meter

Sungai tidak bertanggul di kawasan perkotaan dengan kedalaman sungai kurang dari 3 meter diukur dari tepi sungai, untuk bangunan :

- Perdagangan dan jasa ditetapkan 20 meter

- Industri dan pergudangan ditetapkan 23 meter

- Bangunan umum lainnya ditetapkan 8 meter

Payung hukum diatas merupakan acuan bagi Pemkab Jepara melakukan kebijakan pengelolaan kawasan sempadan sungai, baik sebagai kawasan perdagangan terpadu maupun ruang publik di kawasan perkotaan. 


\section{Analisis terhadap Implementasi Kebijakan}

Untuk melakukan analisis kebijakan, penulis akan membahas pada sisi substansi kebijakan (content of analysis) terlebih dahulu, dengan membandingkan bagaimana implementasi kebijakan kawasan sempadan sungan di Sungai Kanal dan Sungai Wiso. Merujuk teori Grindle, ada 6 indikator yang akan penulis gunakan, yakni kepentingan yang diperngaruhi, tipe manfaat, derajat perubahan, pengambil keputusan, pelaksana program, dan sumber daya yang digunakan. Dengan melakukan perbandingan ini, maka gambaran substansi kebijakan dalam pengelolaan kawasan sempadan sungai di Jepara dapat dipahami lebih jauh.

Tabel 1: Analisis Substansi Kebijakan terhadap Implementasi

Kebijakan Pengelolaan Kawasan Sempadan di Kabupaten Jepara

\begin{tabular}{|c|c|c|}
\hline $\begin{array}{l}\text { Substansi } \\
\text { Kebijakan }\end{array}$ & $\begin{array}{l}\text { Implementasi Kebijakan Kawasan } \\
\text { Sempadan Sungai Kanal }\end{array}$ & $\begin{array}{c}\text { Implementasi Kebijakan Kawasan Sempadan } \\
\text { Sungai Wiso }\end{array}$ \\
\hline $\begin{array}{l}\text { Kepentingan- } \\
\text { kepentingan yang } \\
\text { Dipengaruhi }\end{array}$ & $\begin{array}{l}\text { Warga yang bermukim di kawasan } \\
\text { sempadan Sungai Kanal }\end{array}$ & $\begin{array}{l}\text { - Pemilik kios, lapak, dan warung di kawasan } \\
\text { sempadan Sungai Wiso } \\
\text { - PKL di kawasan Alun - Alun Jepara }\end{array}$ \\
\hline Tipe Manfaat & $\begin{array}{l}\text { Manfaat secara umum : } \\
\text { - Terciptanya taman kota dan } \\
\text { ruang terbuka hijau di kawasan } \\
\text { perkotaan } \\
\text { - Kawasan air dan sempadan Sungai } \\
\text { Kanal terkelola dengan baik } \\
\text { Manfaat secara khusus : } \\
\text { - Warga yang bermukim di kawasan } \\
\text { sempadan Sungai Kanal } \\
\text { o Mendapatkan uang bongkar } \\
\text { dengan besaran yang berbeda- } \\
\text { beda }\end{array}$ & $\begin{array}{l}\text { Manfaat secara umum: } \\
\text { - Aksesabilitas publik dalam menjangkau } \\
\text { kawasan perdagangan } \\
\text { - Terciptanya kenyamanan masyarakat dalam } \\
\text { berbelanja } \\
\text { - Kawasan sempadan Sungai Wiso terkelola } \\
\text { dengan baik } \\
\text { - Menjadikan Sungai Wiso tampak bersih, } \\
\text { indah, dan nyaman. Dengan kebersihan dan } \\
\text { kenyamanan tersebut, Sungai Wiso dapat } \\
\text { dipergunakan untuk olahraga air, seperti } \\
\text { perahu dayung dan kano } \\
\text { - Menumbuhkan (kembali) perekonomian } \\
\text { Jepara. }\end{array}$ \\
\hline
\end{tabular}




\begin{tabular}{|c|c|c|}
\hline Tipe Manfaat & $\begin{array}{l}\text { - Pemerintah } \\
\text { o Proses implementasi kebijakan } \\
\text { dapat dilaksanakan sesuai } \\
\text { rumusan kebijakan } \\
\text { - Tujuan dari implementasi } \\
\text { kebijakan, yaitu membangun } \\
\text { dan mengelola taman kota } \\
\text { yang berada di kawasan } \\
\text { sempadan Sungai Kanal, } \\
\text { tercapai } \\
\text { - Kawasan sempadannya Sungai } \\
\text { Kanal terkelola dengan baik } \\
\text { - Keinginan pemerintah untuk } \\
\text { menjadikan kawasan perko- } \\
\text { taan sebagai kota hijau/ green } \\
\text { city, mulai terpenuhi } \\
\text { Keinginan pemerintah mengim- } \\
\text { plementasikan UU Nomor } 26 \\
\text { Tahun } 2007 \text { tentang penataan } \\
\text { ruang yang mengharuskan } \\
\text { pemerintah daerah mengalo- } \\
\text { kasikan } 30 \text { persen dari total } \\
\text { kawasan perkotaan berupa } \\
\text { ruang terbuka hijau, sedikit } \\
\text { demi sedikit tercapai } \\
\text { - Pemerintah mendapatkan } \\
\text { "modal tambahan" dalam } \\
\text { mempertahankan (kembali) } \\
\text { Adipura }\end{array}$ & $\begin{array}{l}\text { Manfaat secara khusus: } \\
\text { - Pemerintah } \\
\text { o Proses implementasi kebijakan dapat } \\
\text { dilaksanakan oleh pemerintah, sesuai } \\
\text { dengan formulasi kebijakan yang telah } \\
\text { dirumuskan } \\
\text { - Tujuan dari implementasi kebijakan, yaitu } \\
\text { membangun dan mengelola kawasan } \\
\text { perdagangan terintegrasi yang berwujud } \\
\text { Shopping Centre Jepara, tercapai } \\
\text { o Kawasan sempadannya Sungai Wiso } \\
\text { terkelola dengan baik } \\
\text { - Keinginan pemerintah melakukan penataan } \\
\text { kawasan perdagangan yang disinergikan } \\
\text { dengan penataan kawasan sempadan } \\
\text { sungai, tercapai } \\
\text { Pedagang Kaki Lima } \\
\text { o Mendapatkan tempat berjualan yang layak } \\
\text { o Mendapatkan beberapa fasilitas } \\
\text { penunjang, seperti: seperti tenda besar } \\
\text { PKL, air bersih, instalasi listrik, toilet, dan } \\
\text { masjid } \\
\text { - Pemilik kios di kawasan "Tosera"7 } \\
\text { o Mendapatkan prioritas membeli hak sewa } \\
\text { kios di Shopping Centre Jepara, dengan } \\
\text { seperti: instalasi listrik dan air bersih, } \\
\text { masjid, toilet, cleaning service, dan petu- } \\
\text { gas keamanan. } \\
\text { o Mendapatkan subsidi dari pemerintah, } \\
\text { mulai dari } 20 \text { - } 40 \text { persen dari besaran } \\
\text { harga sewa } \\
\text { tahun }\end{array}$ \\
\hline
\end{tabular}




\begin{tabular}{|c|c|c|}
\hline $\begin{array}{l}\text { Derajat Perubahan } \\
\text { yang Ingin Dicapai }\end{array}$ & $\begin{array}{l}\text { - Mengubah kondisi kawasan } \\
\text { sempadan Sungai Kanal menjadi } \\
\text { tertata } \\
\text { - Terciptanya keindahan, kenya- } \\
\text { manan, dan kebersihan di ka- } \\
\text { wasan sempadan Sungai Kanal } \\
\text { - Mengubah imej sungai Kanal } \\
\text { yang dikenal kotor oleh mas- } \\
\text { yarakat menjadi sungai yang } \\
\text { bersih dan nyaman }\end{array}$ & $\begin{array}{l}\text { - Ingin menumbuhkan (kembali) perekonomi- } \\
\text { an di kawasan perkotaan Jepara pasca krisis } \\
\text { moneter di pertengahan tahun } 1998 \\
\text { - Mengubah imej Sungai Wiso yang kotor } \\
\text { menjadi bersih } \\
\text { - Mengubah kawasan sempadan sungai Wiso } \\
\text { yang yang semrawut menjadi tertata }\end{array}$ \\
\hline $\begin{array}{c}\text { Letak Pengambilan } \\
\text { Keputusan }\end{array}$ & $\begin{array}{l}\text { Pemerintah mengambil segala } \\
\text { keputusan yang berkaitan dengan } \\
\text { kebijakan publik, baik di bidang } \\
\text { perencanaan, penganggaran, dan } \\
\text { pelaksanaan kebijakan }\end{array}$ & $\begin{array}{l}\text { Pemerintah mengambil segala keputusan } \\
\text { yang berkaitan dengan kebijakan publik, baik } \\
\text { di bidang perencanaan, penganggaran, dan } \\
\text { pelaksanaan kebijakan }\end{array}$ \\
\hline Pelaksana Program & $\begin{array}{l}\text { Tim Sosialisasi Penataan dan } \\
\text { Penertiban Bangunan di Lokasi } \\
\text { Taman Kota Tepi Sungai Kanal. Tim } \\
\text { ini dibentuk oleh Dinas Pertamanan } \\
\text { dan Tata Ruang Kota (DPTRK) Kab } \\
\text { Jepara }\end{array}$ & Dinas Pekerjaan Umum Kab Jepara \\
\hline $\begin{array}{c}\text { Sumberdaya yang } \\
\text { Digunakan }\end{array}$ & $\begin{array}{l}\text { Sumber daya anggaran, berupa } \\
\text { alokasi anggaran yang bersumber } \\
\text { dari APBD Perubahan Kab. Jepara } \\
\text { Tahun } 2008 \\
\text { - Untuk teknis implementasi } \\
\text { kebijakan sebesar Rp. } \\
\text { 950.000.000,- } \\
\text { - Uang bongkar yang diberikan } \\
\text { kepada warga yang menempati } \\
\text { kawasan sempadan sungai Kanal, } \\
\text { sejumlah Rp. } 33.500 .000,- \text {, } \\
\text { dengan rincian, uang bongkar } \\
\text { untuk bangunan permanen } 5 \\
\text { juta, semi permanen } 2,5 \text { juta, } \\
\text { dan tidak permanen } 1 \text { juta (Lulut, } \\
\text { wawancara penulis, } 26 \text { Oktober } \\
\text { 2010). } \\
\text { - Sumber daya manusia yang } \\
\text { berupa tim teknis pelaksana } \\
\text { implementasi kebijakan di } \\
\text { kawasan sempadan Sungai Kanal }\end{array}$ & $\begin{array}{l}\text { Sumber daya anggaran, berupa alokasi anggaran } \\
\text { yang bersumber dari APBD Kab. Jepara Tahun } \\
2002 \text { dan } 2003 \\
\text { - Pembangunan Shopping Centre Jepara } \\
\text { sebesar } 2 \text { milyar rupiah } \\
\text { (Effendi, wawancara penulis, } 12 \text { September } \\
\text { 2011) } \\
\text { - Pembangunan fasilitas tenda untuk PKL } \\
\text { di area pujasera Shopping Centre Jepara } \\
\text { sebesar 1,6 milyar rupiah } \\
\text { (Rudhi, wawancara penulis, } 30 \text { Oktober } 2010 \text { ) } \\
\text { - Sumber daya manusia yang berupa tim } \\
\text { pelaksana dari Dinas Pekerjaan Umum } \\
\text { Kab Jepara, yang diberikan mandat oleh } \\
\text { pemerintah untuk melaksanakan proses } \\
\text { implementasi kebijakan di kawasan sempadan } \\
\text { Sungai Wiso }\end{array}$ \\
\hline
\end{tabular}


Dari analisis tentang substansi kebijakan pengelolaan kawasan sempadan sungai di Jepara, dapat kita ambil beberapa poin penting. Pertama, peran pemerintah dalam kedua kebijakan publik tersebut cukup dominan, terlihat dari letak pengambilan keputusan kebijakan yang kesemuanya berada di tangan pemerintah (lihat indikator nomor empat, lima, dan enam; dalam Tabel 1 diatas). Kedua, adanya segregasi kepentingan antar masing - masing aktor, dengan tingkat yang berbedabeda. Pada implementasi sungai Kanal, terjadi segregasi kepentingan antara pemerintah sebagai subjek kebijakan dengan warga terdampak yang menempati kawasan sempadan sungai, sehingga diperlukan proses mediasi untuk meminimalkan resiko konflik. Sedangkan implementasi kebijakan di Sungai Wiso, terjadi segregasi kepentingan antara pemerintah dengan pemilik kios di Tosera dan PKL di seputar alun-alun Jepara. Tingkatan segregasi kepentingannya cenderung lunak dan tidak berlarut-larut dibandingkan dengan implementasi di Sungai Kanal. Upaya persuasif yang dilakukan Pemkab Jepara secara kontinyu, yang dibantu beberapa aktor lapangan non pemerintah, segregasi kepentingan ini dapat diselesaikan.

Poin terakhir yang cukup penting adalah penelaahan content of policy dari implementasi kebijakan publik. Kedua implementasi tersebut mempunyai persamaan setting/ keadaan yang melatarbelakangi adanya kebijakan, serta tujuan yang akan dicapai dari kebijakan ini, namun mempunyai bentuk pengelolaan yang berbeda. Pada implementasi kebijakan Sungai Kanal, Pemkab Jepara melakukan pengelolaan kawasan sempadan Sungai Wiso menjadi Shopping Centre Jepara dan Pusat Jajanan Serba Ada/Pujasera Jepara, sedangkan pada kawasan sempadan Sungai Kanal diubah menjadi ruang terbuka hijau dan taman kota. Adapun setting yang melatarbelakangi implementasi kebijakan publik ini adalah kondisi kawasan sempadan sungai yang kotor, kumuh, dan tidak tertata.

Pasca implementasi kebijakan publik, pertanyaan lanjutannya adalah sejauhmana tingkat efektifitas dan efisiensi dari implementasi kebijakan publik ini. Dalam implementasi kebijakan pengelolaan kawasan sempadan Kanal dan Wiso, proses implementasinya cukup efektif. Efektifitas implementasi kebijakannya terlihat dari sisi policy outcome, yaitu pembangunan taman kota dan pembangunan Shopping Centre Jepara. Keinginan politik Pemkab Jepara akhirnya dapat diartikulasikan dalam policy outcome.

Ditinjau dari tingkat efisiensi, khususnya finansial, kedua implementasi kebijakan diatas menghabiskan anggaran publik yang tidak terlalu besar, dan terbilang wajar. Meskipun secara finansial cukup efisien, namun tidak untuk energi yang harus dikeluarkan oleh Pemkab Jepara, khususnya dalam implementasi kebijakan pengelolaan kawasan sempadan Sungai Kanal. Dibutuhkan upaya ekstra parlementarian dalam bentuk negosiasi dikarenakan segregasi kepentingan yang alot antara pemerintah dengan warga terdampak.

Adapun analisis kedua adalah dengan melihat konteks implementasi kebijakan (context of implementation) pengelolaan kawasan sepadan sungai di Jepara. Ada 3 indikator yang akan dilihat, yakni: (1) kekuasaan, kepentingan, dan strategi aktor; (2) karakter kelembagaan dan rezim; dan (3) tingkat kepatuhan dan respon. Ketiga komponen ini akan dipakai untuk memahami konteks kebijakan secara keseluruhan. 
Tabel 2: Analisis Konteks Kebijakan terhadap Implementasi

Kebijakan Pengelolaan Kawasan Sempadan di Kabupaten Jepara

\begin{tabular}{|c|c|c|}
\hline Kon & $\begin{array}{c}\text { Implementasi Kebijakan Kawasan } \\
\text { Sempadan Sungai Kanal }\end{array}$ & $\begin{array}{c}\text { Implementasi Kebijakan Kawasan } \\
\text { Sempadan Sungai Wiso }\end{array}$ \\
\hline $\begin{array}{l}\text { Kekuasaan, } \\
\text { Kepentingan, Dan } \\
\text { Strategi Dari Aktor } \\
\text { Yang Terlibat }\end{array}$ & $\begin{array}{l}\text { - Terjadi segregasi kepentingan yang alot } \\
\text { antara kelompok kepentingan/ interest } \\
\text { group (warga terdampak) dengan } \\
\text { pemerintah } \\
\text { - Kepentingan interest group tidak } \\
\text { diafirmasikan oleh pemerintah } \\
\text { - Munculnya local strongman yang } \\
\text { menentang kebijakan pemerintah. Local } \\
\text { strongman ini bersifat oportunistik }\end{array}$ & $\begin{array}{l}\text { - Tidak ada segregasi kepentingan } \\
\text { yang alot antara interest group } \\
\text { (PKL beserta pedagang di kawasan } \\
\text { sempadan Sungai Wiso) dengan } \\
\text { pemerintah } \\
\text { - Beberapa kepentingan interest } \\
\text { group diafirmasi oleh pemerintah } \\
\text { - Adanya local strongman yang } \\
\text { membantu keberhasilan kebijakan } \\
\text { pemerintah }\end{array}$ \\
\hline $\begin{array}{l}\text { Karakter } \\
\text { Kelembagaan dan } \\
\text { Rejim }\end{array}$ & $\begin{array}{l}\text { - Teknokratis } \\
\text { - Menggunakan cara-cara demokrasi } \\
\text { deliberatif }\end{array}$ & \\
\hline $\begin{array}{l}\text { Tingkat Kepatuhan } \\
\text { dan Adanya Respon } \\
\text { Dari Pelaksana }\end{array}$ & $\begin{array}{l}\text { Memberikan uang bongkar"sebagai salah } \\
\text { satu upaya penyelesaian di lapangan }\end{array}$ & $\begin{array}{l}\text { Menawarkan berbagai bentuk fasilitas } \\
\text { pada kawasan yang baru, bagi } \\
\text { "interest group" }\end{array}$ \\
\hline
\end{tabular}

Ketiga indikator context of implementation diatas telah dikuasai dengan baik oleh pemerintah. Penguasaan pemerintah terhadap kebijakan publik ini terlihat dari minimnya resistensi selama proses implementasi kebijakan. Sebagai pelaksana program, pemerintah mempunyai posisi tawar yang lebih baik dibandingkan warga terdampak. Posisi tawar yang lebih baik ini dikarenakan dua faktor, yakni : (1) pola relasi kuasa antara pemerintah sebagai pemegang otoritas kebijakan publik dengan warga terdampak dan (2) tidak adanya bukti kepemilikan tanah di kawasan sempadan sungai oleh warga terdampak. Sadar terhadap situasi dan kondisi tersebut, pemerintah cukup percaya diri mengawal proses ini sehingga menjadi indikasi kuat keberhasilan implementasi publik.

Dalam implementasi kebijakan publik, Grindle (1980) memaknai proses ini sebagai proses politik dan administratif, maka sepatutnya implementasi kebijakan memberikan dampak bagi konteks kebijakan. Sederhananya, implementasi kebijakan publik seharusnya memberikan perubahan pada lingkungan kebijakan, baik positif atau negatif. Merujuk konsepsi Grindle (1980), dampak dari implementasi kebijakan publik disebut dengan policy outcome. Adapun policy outcome terdiri dari: pertama, dampak terhadap masyarakat, individu, dan kelompok; kedua tingkat penerimaan masyarakat terhadap implementasi kebijakan publik, serta perubahan yang terjadi sebelum dan sesudah proses tersebut.

Selayaknya sebuah proses implementasi kebijakan publik, pengelolaan kawasan sempadan Sungai Wiso menghasilkan keluaran berupa kawasan perdagangan terintegrasi. Wujud fisik dari keluaran ini adalah Shopping Centre Jepara. Sepatutnya, keluaran ini memberikan perubahan sosial bagi lingkungan, yakni memberikan aksesabilitas perdagangan di kawasan perkotaan. Kemudahan 
akses perdagangan ini mengacu pada letak Shopping Centre Jepara yang strategis, yaitu berada dalam kawasan segitiga emas perdagangan Jepara, bersama pasar Jepara Satu/Ratu dan kawasan perdagangan Diponegoro. Selain itu, letak Shopping Centre Jepara tidak lebih dari 100 meter dari pusat pemerintahan. Kemudahan akses perdagangan, serta letaknya yang strategis, menjadi salah satu perubahan positif implementasi kebijakan publik ini.

Bagi kelompok ekonomi mikro (usaha mikro, kecil, dan menengah/UMKM), keluaran ini memberikan harapan tentang (tumbuhnya) perekonomian mikro di Jepara. Shopping Centre Jepara merangkul keberadaan mereka, dari sebelumnya berdagang di seputar alun-alun kemudian ditempatkan ke kawasan Pujasera Shopping Centre Jepara. Selain itu, kelompok ini mendapatkan beberapa fasilitas penunjang di kawasan Pujasera. Kondisi yang tak jauh beda dengan pemilik kios dan toko yang dulunya berdagang di kawasan sempadan Sungai Wiso. Perubahan pasca implementasi kebijakan publik tak hanya persoalan perekonomian semata, melainkan persoalan pembangunan yang ekologis. Kehadiran Shopping Centre Jepara berkontribusi positif terhadap kawasan sempadan Sungai Wiso yang bersih dan nyaman. Adapun dampak atau perubahannya adalah penerimaan masyarakat terhadap proses implementasi kebijakan ini. Hampir sebagian besar masyarakat menerima implementasi kebijakan publik ini, lagipula perubahan kondisi lingkungan sebagai konsekuensi logis dari implementasi kebijakan ini mengarah pada kondisi yang positif.

Dalam konteks implementasi kebijakan publik pengelolaan kawasan sempadan sungai Kanal, menghasilkan keluaran berupa taman kota. Keluaran ini memberikan dampak positif bagi masyarakat, yaitu memberikan aksesabilitas terhadap ruang publik. Melalui ruang publik ini, masyarakat dapat mengartikulasikan kepentingan dan menjalankan fungsi sosialnya. Pemenuhan ruang publik di kawasan perkotaan merupakan tanggungjawab pemerintah. Ketiadaan ruang publik tersebut akan semakin menjauhkan tingkat keadaban maupun tingkat sosial masyarakatnya, bahkan menjadikan wajah kota ke arah "junk cities" (Budiarjo \& Sujarto, 1999). ${ }^{8}$ Selain itu, implementasi kebijakan publik ini memberikan perubahan terhadap imej kawasan.

Sedangkan perubahan dari implementasi kebijakan ini adalah kecenderungan kearah yang lebih baik. Masyarakat menerima proses implementasi kebijakan publik ini, meskipun ada penolakan dari beberapa warga terdampak yang telah lama tinggal di kawasan sempadan Sungai Kanal. Bahkan beberapa warga terdampak ini melakukan upaya perlawanan, seperti memboikot sosialisasi kebijakan yang dilakukan oleh pemerintah, serta menggelar unjuk rasa di kantor Bupati Jepara. Sayangnya, upaya perlawanan ini tidak membuahkan hasil positif bagi warga terdampak.

\section{Evaluasi Kebijakan: Kontribusi, Deliberasi, dan Keberlanjutan}

Dalam diskursus analisis kebijakan publik, khususnya model stagist, evaluasi ditempatkan terakhir (Laswell, 1956). ${ }^{9}$ Meskipun ditempatkan terakhir, keberadaan evaluasi kebijakan sangat penting untuk mengukur tingkat keberhasilan sebuah kebijakan publik. Level evaluasi kebijakan dalam konsepsi Grindle pun sangat penting. Tidak hanya berbentuk penilaian dari berhasil/ tidaknya implementasi kebijakan publik, melainkan memproyeksikan pula policy outcome dengan tujuan/ goals yang telah ditetapkan sebelumnya. Apabila policy outcome sesuai dengan goals, 
lantas faktor/kelebihan apa saja yang mendukung kesesuaian tersebut. Andai policy outcome tidak sesuai, faktor/kekurangan apa yang menghambatnya. Faktor kelebihan/kekurangan tersebut menjadi rekomendasi dalam penyusunan kebijakan publik selanjutnya.

Pendekatan evaluasi kebijakan publik dalam konteks ini menggunakan pendekatan evaluasi formal, dengan evaluasi sumatif sebagai modelnya. Evaluasi model ini bertujuan memantau pencapaian goals dan target formal setelah kebijakan publik diimplementasikan dalam jangka waktu tertentu. Dengan menggunakan 6 (enam) indikator/kriteria evaluasi kebijakan publik, tulisan ini akan mengelaborasi secara cepat implementasi kebijakan publik ini. Keenam indikator yang dimaksud, diantaranya: efektifitas, efisiensi, kecukupan, perataan, responsivitas, dan ketepatan.

Tabel 3: Evaluasi Formal Kebijakan Publik

Pengelolaan Kawasan Sempadan Sungai di Jepara

\begin{tabular}{|c|c|c|}
\hline $\begin{array}{l}\text { Kriteria } \\
\text { Evaluasi }\end{array}$ & $\begin{array}{c}\text { Pertanyaan } \\
\text { Substantif }\end{array}$ & Fakta Lapangan \\
\hline Efektifitas & $\begin{array}{c}\text { Apa hasil yang } \\
\text { diinginkan } \\
\text { telah dicapai? }\end{array}$ & $\begin{array}{l}\text { Goals dari kedua implementasi kebijakan publik ini dapat dicapai. } \\
\text { Keinginan pemerintah mengelola kawasan sempadan sungai, baik } \\
\text { Sungai Wiso dan Kanal, telah terpenuhi. Keluaran dari implementasi } \\
\text { kebijakan ini adalah Shopping Centre Jepara dan taman kota } \\
\text { yang terletak di kawasan sempadan sungai. Konklusinya, kedua } \\
\text { implementasi kebijakan publik ini dapat dikatakan efektif. }\end{array}$ \\
\hline Efisiensi & $\begin{array}{l}\text { Seberapa } \\
\text { banyak } \\
\text { usaha yang } \\
\text { diperlukan } \\
\text { untuk } \\
\text { mencapai } \\
\text { hasil yang } \\
\text { diinginkan? }\end{array}$ & $\begin{array}{l}\text { Dalam kriteria ini, efisiensi tidak hanya diukur melalui dimensi finansial, } \\
\text { melainkan tindakan pemerintah dalam implementasi kebijakan } \\
\text { publik ini. Apabila menggunakan ukuran finansial, anggaran publik } \\
\text { yang dikeluarkan untuk implementasi kebijakan publik ini terbilang } \\
\text { wajar. Anggaran pemerintah untuk pembangunan Shopping Centre } \\
\text { Jepara sebesar } 2 \text { milyar rupiah, sedangkan pembangunan fasilitas } \\
\text { Pujasera di sebelahnya menghabiskan anggaran tak kurang dari } 1,6 \\
\text { milyar. Sedangkan untuk pembangunan taman kota, termasuk upaya } \\
\text { relokasi warga, pemerintah mengeluarkan anggaran publik sebesar } \\
\text { Rp 983.500.000,00. } \\
\text { Apabila menggunakan ukuran tindakan, pemerintah cenderung kurang } \\
\text { efisien, khususnya dalam implementasi kebijakan publik di kawasan } \\
\text { sempadan Sungai Kanal. Pemerintah mengeluarkan banyak energi } \\
\text { dalam implementasi ini dikarenakan adanya segregasi kepentingan } \\
\text { antara pemerintah dengan warga yang cukup alot. Sedangkan dalam } \\
\text { konteks implementasi kebijakan di kawasan sempadan Sungai Wiso, } \\
\text { energi yang dikeluarkan pemerintah terhitung minim. }\end{array}$ \\
\hline
\end{tabular}




\begin{tabular}{|c|c|c|}
\hline $\begin{array}{l}\text { Kriteria } \\
\text { Evaluasi }\end{array}$ & $\begin{array}{l}\text { Pertanyaan } \\
\text { Substantif }\end{array}$ & Fakta Lapangan \\
\hline Kecukupan & $\begin{array}{l}\text { Seberapa jauh } \\
\text { pencapaian } \\
\text { hasil yang } \\
\text { diinginkan } \\
\text { dalam } \\
\text { pemecahan } \\
\text { masalah? }\end{array}$ & $\begin{array}{l}\text { Kedua keluaran tersebut nyatanya dapat dicapai oleh implementasi } \\
\text { kebijakan publik ini. Problematika tata kelola kawasan sempadan } \\
\text { sungai yang kurang baik, minimnya ruang publik, dan kesemrawutan } \\
\text { kawasan perkotaan Jepara, setidaknya mampu dijawab oleh kedua } \\
\text { implementasi kebijakan publik ini. Konklusinya, sejauh ini kedua } \\
\text { implementasi kebijakan publik ini mampu memenuhi ekspektasi publik } \\
\text { terhadap problematika yang terjadi di kawasan perkotaan. }\end{array}$ \\
\hline Perataan & $\begin{array}{l}\text { Apakah biaya } \\
\text { dan manfaat } \\
\text { didistribusikan } \\
\text { merata? }\end{array}$ & $\begin{array}{l}\text { Dalam kedua implementasi kebijakan ini, biaya dan manfaat tidak } \\
\text { didistribusikan secara merata. Dalam konteks Sungai Wiso, aktor yang } \\
\text { terpapar implementasi kebijakan mendapatkan biaya serta manfaat } \\
\text { yang lebih baik dibandingkan dengan kelompok kepentingan/ interest } \\
\text { group yang berada kawasan sempadan Sungai Kanal. }\end{array}$ \\
\hline Responsivitas & $\begin{array}{l}\text { Apakah hasil } \\
\text { kebijakan } \\
\text { memuaskan } \\
\text { kebutuhan, } \\
\text { preferensi, atau } \\
\text { nilai kelompok } \\
\text { tertentu? }\end{array}$ & $\begin{array}{l}\text { Keluaran dari kedua implementasi kebijakan publik ini memuaskan } \\
\text { preferensi masyarakat maupun pemerintah. Kehadiran kedua keluaran } \\
\text { diatas memuaskan pemerintah dalam upaya mengelola kawasan } \\
\text { sempadan sungai, penataan kawasan perkotaan, serta kampanye } \\
\text { pemerintah dalam mendapatkan Adipura. Sedangkan menurut } \\
\text { masyarakat, kedua keluaran diatas manfaatnya dapat dirasakan. Jadi } \\
\text { kedua implementasi kebijakan publik seperti yang telah dipaparkan } \\
\text { diatas, dapat dikatakan responsif. }\end{array}$ \\
\hline Ketepatan & $\begin{array}{l}\text { Apakah hasil } \\
\text { (tujuan) yang } \\
\text { diinginkan } \\
\text { benar-benar } \\
\text { berguna atau } \\
\text { bernilai? }\end{array}$ & $\begin{array}{l}\text { Keluaran dari kedua implementasi kebijakan publik ini sangat berguna } \\
\text { dalam mengatasi berbagai persoalan di kawasan perkotaan. Ini } \\
\text { berarti, keluaran yang dihasilkan sesuai dengan proyeksi awal. }\end{array}$ \\
\hline
\end{tabular}

Merujuk pada keenam kriteria evaluasi diatas, dapat disimpulkan bahwa implementasi kebijakan publik terkait kawasan sempadan Sungai Wiso dan Kanal, sesuai dengan proyeksi awal kebijakan. Ada kesesuaian antara keluaran yang dihasilkan dengan goals yang telah ditetapkan. Sampai sejauh ini, keluaran tersebut mampu menjawab rumusan persoalan yang terjadi di kawasan sempadan sungai (pada khususnya) dan tata kelola kawasan perkotaan pada (umumnya). Memang kriteria perataan tidak terpenuhi secara optimal, namun kedua keluaran ini sudah memenuhi kelima kriteria yang lain, terutama kriteria efektif, efisien, dan ketepatan.

Beranjak dari proses evaluasi kebijakan publik diatas, ada beberapa catatan terkait kelebihan/ kekurangan dari kedua proses implementasi kebijakan publik ini. Pertama, implementasi kebijakan publik ini didesain untuk menata dan mengelola kawasan sempadan sungai. Dalam kenyataannya, pemerintah mempunyai tujuan jangka panjang, yakni memperoleh Adipura sebagai simbol kota bersih di Indonesia. Oleh sebab itu, Pemkab Jepara mengkampanyekan pula beberapa kebijakan dan program, antara lain: pengelolaan kawasan sempadan sungai, penataan kawasan perkotaan, 
pembangunan taman kota, dan program bersih-bersih kota. Melalui beragam kebijakan dan program tersebut, pemerintah selalu mendapatkan Adipura, mulai dari 2003 sampai sekarang. Kedua implementasi kebijakan tersebut berkontribusi positif terhadap pencapaian Adipura untuk Kab Jepara.

Kedua, implementasi kebijakan publik tersebut pemerintah menggunakan cara-cara deliberatif. Dalam tradisi deliberatif, komunikasi memegang peranan penting didalam implementasi kebijakan. Kedua implementasi kebijakan diatas cenderung mengedepankan komunikasi, seperti sosialisasi dan negosiasi.

Ketiga, keberlanjutan pasca implementasi kebijakan publik. Keberlanjutan pasca implementasi kebijakan publik biasanya menjadi persoalan lanjutan bagi pemerintah. Dalam konteks implementasi kebijakan pengelolaan kawasan sempadan Sungai Kanal ini, Pemkab Jepara melakukan upayaupaya sustainabilitas, seperti perawatan taman kota dan fasilitas publik lainnya. Sedangkan dalam konteks pengelolaan sungai beserta kawasan sempadan Sungai Wiso, upaya sustainabilitas belum cukup optimal. Untuk kawasan Pujasera upaya sustainabilitas sudah optimal, namun tidak untuk Shopping Centre Jepara. Tingkat keramaian Shopping Centre Jepara-pun tidak seramai kawasan Pujaseranya.

\section{Waterfront City Development dalam Pengelolaan Sempandan Sungai}

Lahirnya pendekatan ekologi dalam ilmu sosial dimulai pada tahun 1920. ${ }^{10}$ Ilmuwan sosial yang bernama Robert Park, Ernest Burgess, dan Louis Wirth dari Universitas Chicago; mengembangkan sebuah basis teori yang bernama "Urban Sociology" atau sosiologi perkotaan. "Urban Sociology" yang dikembangkan oleh ketiga ilmuwan di atas, menjadi sebuah "epistemis community" bernama mazhab Chicago ("Chicago School"). ${ }^{11}$ Mazhab ini berlangsung berlangsung dari tahun 1920 hingga 1940-an.

Dalam sosiologi perkotaan, ada 2 konsep utama untuk memahami perkembangan kawasankawasan perkotaan, yaitu (1) pendekatan ekologis/aliran humanis ekologi dalam analisis perkotaan, dan (2) karakteristik urbanisme sebagai jalan hidup (Giddens, 2002: 574). ${ }^{12}$ Pendekatan ekologi berkeyakinan bahwa sebuah kota tidak muncul dan tumbuh secara acak, seperti halnya makhluk hidup di alam yang terdistribusi secara sistemik. Kemunculan dan perkembangan perkotaan merupakan sesuatu yang "by design", dan bukan sesuatu yang "given". Ada campur tangan pemerintah setempat dalam mendesain dan mengembangkan sebuah kawasan menjadi perkotaan.

Lingkungan di perkotaan, baik secara langsung maupun tidak langsung, memberikan berbagai keuntungan yang dapat diproyeksikan dalam pengembangan kota di masa mendatang. Sebagai contohnya, kawasan perkotaan dalam masyarakat modern seperti sekarang ini mempunyai kecenderungan memulai pengembangan kawasan tersebut di sepanjang sungai, pantai, dataran subur, ataupun jalur perdagangan dari kereta api (Giddens, 2002). Beberapa negara maju, semisal Singapura, Korea Selatan, dan Jepang; telah mengembangkan kawasan ekologis, seperti kawasan tepian sungai, dataran rendah, dan tepian pantai; sebagai kawasan wisata maupun ruang-ruang publik di perkotaan. 
Kawasan perkotaan dapat direkayasa dari sebuah kawasan yang berada di sepanjang aliran sungai, dataran rendah, hingga kawasan perdagangan yang bersinggungan dengan jalur kereta. Sebuah kawasan ekologis dengan berbagai potensinya, jika diproyeksikan secara tepat dengan pengelolaan yang baik, akan memberikan nilai tambah bagi kawasan tersebut, baik berbentuk nilai estetika, nilai ekonomi, maupun nilai sosialnya. Secara garis besar, pendekatan ekologi menitikberatkan basis teorinya pada proses kemunculan dan perkembangan kota yang tidak terjadi secara acak, melainkan by design.

Menggunakan tesis urban sociology mazhab Chicago, implementasi kebijakan publik diatas termasuk kedalam tipologi pendekatan ekologis dalam analisis perkotaan atau sering disebut ecological approach. Pendekatan ini berkeyakinan, sebuah kota tidak muncul secara tiba-tiba melainkan didahului oleh sebuah proses perencanaan.

Satu contoh konkritnya adalah kawasan perkotaan di Jawa dimana alun-alun menjadi sentrum utamanya. Bangunan-bangunan di seputar alun-alun, tata letak kotanya hampir sebagian besar sama, meskipun ada beberapa varian yang berbeda. Masjid agung ditempatkan di sebelah barat alun-alun, kawasan perkantoran ditempatkan di sebelah timur, dan penjara (seringkali) ditempatkan di sebelah utara. Desain tata kota diatas merupakan "pakem" di Jawa yang turun temurun.

Meskipun tipologi kawasan perkotaannya terbilang kecil, namun Jepara mempunyai komitmen tinggi dalam pengembangan kawasan-kawasan yang bersinggungan dengan perairan, seperti sungai dan pantai. Contoh konkrit dari komitmen ini adalah : (1) Membuka perijinan pembangunan resort di beberapa kawasan sempadan pantai di Jepara (Ocean View, JeParadise, Palm Beach) dengan tetap mengacu pada regulasi yang berlaku; (2) Membuka peluang investasi pengelolaan kawasan pantai di Jepara (Pantai Kartini dan Pantai Tirta Samudra); dan (3) Mengelola kawasan sempadan Sungai Kanal dan Wiso.

Beberapa kebijakan publik diatas merupakan salah satu bentuk public service good practice, serta aktualisasi dari konsep waterfront city development. Dalam studi perencanaan wilayah kota, konsep waterfront city development merupakan sebuah konsep pengembangan kawasan perkotaan yang menempatkan kawasan perairan sebagai objek. Waterfront city development dapat didefinisikan sebagai proses pembangunan yang memiliki kontak visual dan fisik dengan air. Perencanaan awal dari implementasi kebijakan publik ini, memang tidak secara langsung merujuk konsep waterfront city development sebagai basis utamanya. Meskipun tidak (secara langsung) merujuk pada konsepsi tersebut, policy outcome dari kedua implementasi kebijakan ini sudah mengarah pada konsepsi waterfront city development.

Menurut Prabudiantoro (1997), pembangunan kawasan-kawasan di perkotaan dapat dikatakan menggunakan konsep waterfront city development, apabila memenuhi 5 kriteria umum, yakni : (1) Berlokasi di tepi suatu wilayah perairan yang besar (sungai, danau, laut, dan sebagainya), (2) Biasanya merupakan area pelabuhan, perdagangan, permukiman, dan pariwisata, (3) Mempunyai fungsi utama sebagai tempat rekreasi permukiman, industri, dan pelabuhan, (4) Pemandangan berorientasi ke arah perairan, dan (5) Pembangunannya dilakukan ke arah vertikal horisontal. Kedua implementasi kebijakan pengelolaan kawasan sempadan Sungai Kanal dan Wiso, pada 
kenyataannya, mampu memenuhi kelima kriteria diatas. Merujuk pada kelima kriteria diatas, implementasi kebijakan publik ini dapat dikatakan menggunakan konsep waterfront city development.

\section{Kesimpulan}

Implementasi kebijakan publik dalam bentuk pengelolaan sungai beserta kawasan sempadan di Kabupaten Jepara, dengan menggunakan analisis implementasi kebijakan yang dikenalkan Grindle dapat dikatakan berhasil. Dalam content of policy, implementasi kebijakan publiknya bersifat teknokratis. Pemerintah mempunyai peran yang cukup dominan dalam kedua kebijakan tersebut, mulai dari pengambilan keputusan, penentuan siapa pelaksana program di lapangan, perencanaan teknis kebijakan, serta perencanaan penganggaran. Peran sentral inilah yang menjadi kausa keberhasilan implementasi kebijakan tersebut.

Dalam context of implementation, pemerintah menguasai dengan baik ketiga indikator Grindle tersebut sehingga hambatan ataupun resistensi dapat diminimalkan. Pemerintah sebagai pelaksana program mempunyai posisi tawar yang lebih baik dibandingkan dengan warga terdampak, khususnya pada aspek legal formal dan pola relasi kuasa.

Secara teoritis, implementasi kebijakan berhasil jika policy statement dapat tersampaikan menjadi policy outcome. Dalam konteks implementasi kebijakan di sungai Kanal, dapat dikatakan berhasil meskipun belum sepenuhnya optimal. Keinginan pemerintah (policy statement) mengelola kawasan sempadan Sungai Kanal tercapai dengan kehadiran pembangunan taman kota, tepatnya di sepanjang jalan KM Sukri. Adanya taman kota ini semakin melengkapi ruang terbuka hijau di kawasan perkotaan Jepara. Keberadaan taman kota ini dapat dimanfaatkan sebagai ruang publik oleh masyarakat. Sedangkan dalam konteks implementasi kebijakan di Sungai Wiso, keinginan politik pemerintah menghidupkan kembali perekonomian Jepara terwujudkan dalam kebijakan pengelolaan sungai beserta kawasan sempadan sungai Wiso. Policy statement ini kemudian tersampaikan menjadi policy outcome berupa pembangunan Shopping Centre Jepara. Dalam policy statement ini, pembangunan Shopping Centre Jepara sebagai kawasan perdagangan yang terintegrasi, nyatanya kawasan ini memberikan fungsi-fungsi lain, semisal sebagai ruang publik perkotaan, tempat wisata kuliner, dan wisata keluarga.

Sedari awal kebijakan pengelolaan sungai beserta kawasan sempadan sungai Kanal dan Wiso, tidak secara langsung mengacu konsepsi waterfront city development sebagai basis utama dari implementasi kebijakan publik ini. Implementasi kebijakan publik ini tidak didesain untuk konsepsi waterfront city development, melainkan bentuk kepatuhan pemerintah terhadap sumber legal formal, khususnya undang-undang tentang penataan ruang dan pengelolaan lingkungan hidup. Selain itu, implementasi kebijakan publik ini merupakan bentuk akomodatif dari hasil Musrengbangda, serta kemauan politik pemerintah.

Merujuk pada tipologi Breen (1996) tentang bentuk-bentuk waterfront city development, pembangunan ruang terbuka hijau dan Shopping Centre Jepara di kedua kawasan sempadan sungai merupakan salah satu bentuk dari mixed-used waterfront. Tipologi ini banyak dipakai oleh kota-kota di belahan negara dunia, meskipun implementasi kebijakan ini tidak (secara implisit) 
mengacu pada konsepsi tersebut. Namun marwah waterfront city development sangat terasa dalam implementasi kebijakan ini, meskipun implementasi kebijakannya tidak didesain menganut konsepsi tersebut. Keberhasilan implementasi kebijakan publik di kedua kawasan sempadan sungai ini dapat menjadi good practice bagi daerah lain, sekaligus memperkaya good practice yang sudah ada di Indonesia. Dan alangkah lebih baik jika good practices ini dapat direplikasi oleh daerah lain, sehingga tidak berhenti menjadi sebuah good practice semata. []

\section{Ucapan Terima Kasih}

Saya mengucapkan terima kasih kepada semua pihak yang telah membantu selama proses penelitian berlangsung, khususnya kepada seluruh informan penulis. Selain itu, saya mengucapkan terima kasih kepada Nur Azizah yang berkenan menjadi mentor saya selama proses analisis data dan proses penulisan berlangsung.

\section{Pendanaan}

Penulis tidak menerima bantuan pembiayaan untuk penelitian, kepenulisan, dan publikasi dari pihak manapun.

\section{Catatan}

1 Dalam Arus Balik, Pramoedya Ananta Toer menarasikan Jepara sebagai salah satu bandar terkenal di pesisir utara Jawa. Selain Jepara, beberapa bandar terkenal saat itu, antara lain : Malaka, Tuban, Lasem, dan Sunda Kelapa. Posisi bandar Jepara sangat strategis dalam jalur perdagangan Maluku - Malaka. Oleh sebab itu, Kesultanan Demak (yang tidak mempunyai bandar) menaklukkan Jepara dan menjadikannya sebagai kerajaan vasal.

2 Teori analisis kebijakan terbagi atas dua pemahaman, yaitu "lay theory" dan "scientific theory". "Lay theory" adalah teori yang dikembangkan dari pengalaman, atau dalam definisi Schermerhorn sebagai "developed by themselves or learned from others over time and as a result of their experiences". Adapun "scientific theory" adalah teori yang dikembangkan melalui metode ilmiah, atau "that are developed through scientific methods".

3 Baik sungai Wiso maupun sungai Kanal mempunyai lebar sekitar 10 meter, dengan ke dalaman 6-7 meter untuk sungai Kanal dan 3-4 meter untuk sungai Wiso.

4 Hulu kedua sungai ini berada di Desa Beringin dan Desa Sumosari, Batealit seluas 25,75 $\mathrm{km}^{2}$. Pada medio 1997 hingga 1999, terjadi "booming meubel" di Jepara yang menyebabkan masifnya pembalakan liar/"illegal logging" di lereng Gunung Muria. Pembalakan liar merusak hutan seluas sekitar 47.000 hektar.

5 Pada UU No. 32 Tahun 2009 Pasal 1 Ayat 3 dijelaskan pula tentang perlindungan dan pengelolaan lingkungan hidup. Perlindungan dan pengelolaan lingkungan hidup adalah upaya sistematis dan terpadu yang dilakukan untuk melestarikan fungsi lingkungan hidup dan mencegah terjadinya pencemaran dan/atau kerusakan lingkungan hidup yang meliputi perencanaan, pemanfaatan, pengendalian, pemeliharaan, pengawasan, dan penegakan hukum. 
Pasal ini secara tersurat menganggap pentingnya dimensi ekologis dalam sebuah kebijakan pemerintah di kawasan perkotaan. Di dalam pasal ini diatur pula, berbagai tahapan yang perlu dipersiapkan oleh pemerintah ketika hendak mengimplementasikan kebijakan yang berkaitan dengan dimensi ekologis.

6 RTRWP Jawa Tengah merupakan arahan kebijakan dan strategi pemanfaatan ruang wilayah daerah yang menjadi pedoman bagi penataan ruang wilayah daerah yang merupakan dasar dalam penyusunan program pembangunan. Dalam case ini, RTRWP yang dimaksud adalah RTRWP Jawa Tengah yang di-legal formal-kan dengan Peraturan Daerah (Perda) No. 21 Tahun 2003 Tentang Rencana Tata Ruang Wilayah Propinsi Jawa Tengah.

7 Tosera adalah salah satu kawasan perniagaan di Jepara. Kios yang berada di kawasan Tosera ini umumnya dibangun di kawasan sempadan dan membelakangi Sungai Wiso. Kawasan Tosera merupakan cikal bakal Shopping Centre Jepara.

8 Istilah "junk cities" merujuk pada kota-kota yang berwajah monoton, serupa, membosankan, dan tidak memiliki identitas.

9 Model stagist pertama kali diperkenalkan oleh Harold Laswell. Laswell melakukan penelitian terhadap keseluruhan proses pembuatan kebijakan publik, dan membagi masing-masing proses tersebut dengan istilah fase atau tahap ("stage"). Istilah "stagist" sendiri merujuk pada seperangkat langkah-langkah yang terpisah dan berurutan, serta secara konsepsi diproyeksikan sebagai sesuatu yang berjalan sesuai kronologi, mulai dari inisiatif, formulasi, pengambilan keputusan, hingga evaluasi.

10 Kata ekologi merujuk pada disiplin ilmu alam yang mempelajari proses adaptasi makhluk hidup dengan lingkungan sekitar. Makhluk hidup di alam semesta cenderung terdistribusi secara sistemik, seperti halnya keseimbangan alam maupun antar masing-masing spesies

11 Term mazhab Chicago merujuk pada tempat di mana basis teori ini dikembangkan (Universitas Chicago).

12 "Urbanisme as Way of Life" merupakan tesis dari Louis Wirth. Urbanisme menurut Wirth, dapat dimaknai sebagai gaya hidup khas perkotaan. "Urbanisme" sendiri hanya dapat ditemukan di wilayah-wilayah perkotaan, dan bukan pedesaan. Menurut Wirth, sebuah wilayah/kawasan dapat disebut "kota" apabila mempunyai ukuran yang cukup luas, padat penduduknya, dan masyarakatnya heterogen. Dalam kawasan yang dilabeli dengan "kota", muncul gejala-gejala "urbanisme", seperti individualistik, korupsi, dan kriminalitas. "Urbanisme merupakan bentuk eksistensi sosial dari sebagian besar masyarakat," lanjut Wirth. Sebagai ekspresi dari eksistensi sosial, "urbanisme" memunculkan mentalitas perkotaan, baik sikap, pola pikir, maupun sikap/ kepribadian. 


\section{Daftar Pustaka}

Banjir di Jepara itu Sebuah Peringatan. (2005). Suara Merdeka.

Breen, A. E. (1996). The New Waterfront: A Worldwide Urban Succes Story. New York: Mc Graw Hill. Budiarjo, E., \& Sujarto, D. (1999). Kota Berkelanjutan. Bandung: Alumni.

Dunn, W. N. (1999). Pengantar Analisis Kebijakan Publik. Yogyakarta: Gadjah Mada University Press. Giddens, A. (2002). Sociology Fourth Edition. Cambridge: Polity Press.

Grindle, M. S. (Ed.). (1980). Politics and Policy Implementation in The Third World. Princeton: Princeton University Press.

Laswell, H. (1956). The Decision Process: Seven Categories of Functional Analysis. Maryland: University of Maryland.

Lombard, D. (2000). Nusa Jawa Silang Budaya: Kajian Sejarah Terpadu (Bagian II, Jaringan Asia). Jakarta: PT Gramedia Pustaka Utama.

Menyimpan Sejarah Kehebatan Ratu Sungainyamat. (2008). Suara Merdeka.

Narbuko, C. (2003). Metodologi Penelitian. Semarang: Bumi Aksara.

Prabudiantoro, B. (1997). Kriteria Citra Waterfront City (tesis tidak dipublikasikan). Semarang: Universitas Diponegoro.

Santoso, P. (2010). Analisis Kebijakan Publik. Yogyakarta: Polgov.

Sarantakos, S. (1999). Social Research. Basingstoke: Mc Millan.

Subarsono, A. (2006). Analisis Kebijakan Publik. Yogyakarta: Pustaka Pelajar.

Toer, P. A. (2002). Arus Balik (Cetakan Kelima). Jakarta: Hasta Mitra.

Undang Undang No. 32 Tahun 2009 tentang Perlindungan dan Pengelolaan Lingkungan Hidup

Peraturan Daerah Propinsi Nomor 21 Tahun 2003 tentang Rencana Tata Ruang Wilayah Propinsi Jawa Tengah

Peraturan Daerah Kabupaten Nomor 6 Tahun 1998 tentang Rencana Tata Ruang Wilayah Kabupaten Daerah Tingkat II Jepara

Yin, R. K. (2006). Studi Kasus: Desain dan Metode. Bandung: PT Raja Grafindo Persada.

Yuwono, M. (2009). Visi Pembangunan Waterfront City: Suatu Tinjauan Budaya. Buletin Tata Ruang Edisi September- Oktober.

\section{Daftar Informan}

Anis, Pegawai Bappeda Pemerintah Kabupaten Jepara, 27 Oktober 2010, pukul 10.23 WIB Rudhi BS, kepala Bappeda Pemerintah Kabupaten Jepara, 30 Oktober 2010, pukul 21.51 WIB Lulut ST, pegawai Dinas Pertamanan dan Tata Ruang Kota (DPTRK) Kabupaten Jepara, 26 Oktober 2010, pukul 12.57 WIB

Effendi, kepala Dinas Pekerjaan Umum Kabupaten Jepara Tahun 2002-2003, 12 September 2011, pukul 18.15 WIB 


\section{Tentang Penulis}

Yoga Putra Prameswari adalah peneliti dan penulis lepas. Pernah bekerja untuk Centre for Electoral Survey (CES) dan Institute for Development and Economic Analysis (IDEA) Yogyakarta. Beberapa tahun terakhir, penulis menggeluti isu industri ekstraktif, transparansi dan akuntabilitas publik, open data, dan desa. 